BISMA

(Bisnis dan Manajemen)
Volume 13, Issue 2, April 2021, 94-107

ISSN 2549-7790 (Online)

ISSN 1979-7192 (Print)

DOI: 10.26740/bisma.v13n2.p94-107

https://journal.unesa.ac.id/index.php/bisma/index

\title{
Unlocking brand equity through brand image, service quality, and customer value
}

\author{
Rina Dewi ${ }^{1 *}$, Tanti Handriana ${ }^{2}$ \\ ${ }^{1}$ Universitas 45 Surabaya, Indonesia \\ ${ }^{1,2}$ Universitas Airlangga, Indonesia
}

\begin{abstract}
Building brand equity in customers is essential to create long-term relationships with customers. With high brand equity, the company maintains loyal customers because consumers believe in its quality or service. This study aims to determine how brand image, satisfaction with service quality, and customer value affect brand loyalty and equity. This research is a quantitative study which collected 215 samples with purposive sampling method. The analysis technique uses Structural Equation Modeling. The results show a brand image, service quality, and customer value are positively affect brand loyalty. The loyal customer attitude influence long-term brand equity. This finding offers a theoretical and practical contribution to developing a marketing management strategy about unlocking brand equity through a strong brand image, service quality, and customer value in the banking sector.
\end{abstract}

Keywords: brand equity; brand image; brand loyalty; customer value; service quality.

Received: May 4, 2020; Accepted: July 24, 2020; Published; April 27, 2021

*Corresponding author

Email: rinadewisoesyra@gmail.com

\section{To cite this document:}

Dewi, R., \& Handriana, T. (2021). Unlocking brand equity through brand image, service quality, and customer value. BISMA (Bisnis dan Manajemen), 13(2), 94-107. https://doi.org/10.26740/bisma.v13n2.p94-107.

\section{INTRODUCTION}

The economic and social environment changes enforce fierce competition in the banking industry and brings the consequences of banks' evolution of services (Altaf \& Mahadin, 2019; Akbar et al., 2019). Amid a fierce banking sector competition, PT Bank Central Asia Tbk (BCA) managed to grow from $\$ 13.437$ billion in 2019 to $\$ 14.917$ billion in 2020, or increase about eleven percent, along with the nine banks from China, the United States, India, and Canada. BCA management is committed to always providing service excellence for customers by serving 22 million customer accounts, processes millions of transactions every day supported by 1,252 branch offices, 17,607 ATMs, and BCA mobile and Klik BCA, which can be accessed anywhere and anytime (Kafe BCA, 2020). 
Unlocking brand equity through brand image, service quality, and customer value

Bank in Indonesia carries out its functions based on economic democracy and prudential principles (Asnawi et al., 2019). Its function is collecting and channelling public funds for supporting economic growth and national stability towards improving people's living standards (Otoritas Jasa Keuangan, 2004). The bank has experienced developments by providing various financial services (Rambocas \& Arjoon, 2019).

The state and private banks in Indonesia are competing to offer an advantage by providing complete facilities to attract customers (Foroudi et al., 2019). Hence, banks must pay attention to customers' needs and desires to create conditions of mutual need that form a customer's commitment (Monferrer et al., 2019). On the other side, the customer's trust factor in the bank is also essential (Saleh et al., 2017). A positive image of the bank forms customer trust (Bapat, 2017). It takes effort to pursue and maintain while innovate, create new products, increase product quality, and maintain competitive production costs.

Previous research conducted by Hapsari et al. (2017), Razzaq et al. (2019), Chakraborty (2019), Kataria \& Saini (2019), and Liu et al. (2018) stated service quality, customer value, customer satisfaction, and brand image as antecedents of customer loyalty, and these constructs have this reciprocal relationship in various service industries. By having a brand image, a good customer trust in banks will be formed (Liu et al., 2018; Kim \& Lee, 2020; Hoang, 2019; Saleh et al., 2017), and this becomes long-term factor influence customer to not switch to another bank (Hapsari et al., 2017). Trust in banks is formed because of the ability and expertise in providing services to banks (Akroush \& Mahadin, 2019; Hoang, 2019).

Customer satisfaction has a close relationship with loyalty (Hamouda, 2019; Espinosa et al., 2018; Saleh et al., 2017). Good quality service is one of the keys to win the business competition (Hapsari et al., 2017; Hoang, 2019). This quality is achieved by exceeding customers' expectations, providing products and services at an acceptable price level, creating value for customers, and generating profits for the company (Saleh et al., 2017).

Service quality must meet customers' expectations so that the benefits provided by customers to the company can exceed the target set plan (Altaf et al., 2017). Customer satisfaction is significantly related to the perceived quality (Kataria \& Saini, 2019; Kamath \& Prabhu, 2019; Akroush \& Mahadin, 2019; Hamaouda, 2019). Meanwhile, customer satisfaction yields from the perceived performance and expected performance gap (Kotler \& Keller, 2016). If the customer's performance does not meet customer expectations, it will lead to customer loss in the company (Saleh et al., 2017). Moreover, service quality enhances customer satisfaction and loyalty to the bank (Mohsin \& Aftab, 2013; Bapat, 2017).

Brand equity must get serious attention from the company because a strong and highvalue brand gives both rational counts and consumer emotions (Liu, 2018). A brand can have high value because it carries out the brand-building activity, communication Saleh et al. (2017), and other efforts to strengthen the brand (Kataria \& Saini, 2019). The brand is a long-term wealth in a company and built as brand equity (Rambocas \& Arjoon, 2019; Rubio et al., 2019). The critical role of building and maintaining brand images provides quality services and brand value in building brand loyalty ultimately forming brand equity (Boateng et al., 2019; Pérez et al., 2019).

Bank Central Asia (BCA) has contributed to national banking industry development (BCA, 2020). BCA plays an active role as a leading transactional bank and has a stake in growing and driving business and Indonesia's economy. BCA strives to improve competitive 
advantage in the banking industry continuously by providing quality services to provide satisfaction. Therefore, it can foster positive brand image and information so that customers will trust and loyal to the banks (Hamouda, 2019; Kartika et al., 2019; Pan \& Ha, 2019). BCA has main financial services, such as savings and deposits. In providing excellent service quality to customers, BCA imposes several administrative costs each month according to deposit type.

Nevertheless, BCA must maintain brand loyalty because loyalty is an essential concept in intense competition conditions with limited growth (Kataria \& Saini, 2019; Liu et al., 2018). Therefore, choosing BCA as an object of research compared to other banks is because of BCA positive image as The Most Efficient Bank, The Most Valuable Bank, and The Best Performance Bank by Infobank Awards 2019 (Putra, 2020).

Therefore, this study aims to identify the influence of a brand image, service quality, and customer value on brand equity. If previous research has examined a lot about the influence of customer trust and service quality on bank image in the banking sector, this research aims to analyze further the influence of brand image and service quality on brand equity.

\section{Brand Image}

Brand image is a rational and emotional perception of a particular brand (Razzaq et al., 2019). It is derived from consumer confidence in the brand both functionally and symbolically. A good brand image must pay attention to the product's unique characteristics (Espinosa et al., 2018).

Indicators of a brand image are friendly/unfriendly (easily recognized brand by consumers), modern or outdated (has a contemporary model, not outdated), useful/not (perceived benefits), popular/unpopular (familiarity to the consumer's mind), gentle/harsh (the texture of the product is smooth or not rough), and artificial/natural (the authenticity of supporting product/service components) (Alić et al., 2020; Chang, 2020; Flores-Hernández et al., 2020; Guci et al., 2020). A high-quality brand will give satisfaction to consumers so that the brand will be memorable (Chakraborty, 2019; Rubio et al., 2019). With consumers fulfilled their expectations of the product or service brand, the consumer will keep that memory in their mind and provide references to potential customers by giving positive information (Monferrer et al., 2019; Pan \& Ha, 2019; Rubio et al., 2019). Brand image touches consumers' psychological to overcome marketing problems aspects because it is difficult to emulate by competitors (Espinosa et al., 2018).

Brand image acts as necessary for consumers to distinguish a brand from its rivals when it is difficult to compare brands using quality features (Hoang, 2019; Rubio et al., 2019). Brand image is important because a positive perception is formed with all its attributes (Rambocas \& Arjoon, 2019). Therefore, we hypothesize:

H1: Brand image has a positive effect on brand loyalty.

\section{Service Quality}

Service quality measures the services expected by consumers and the services received (Streukens \& Leroi-Werelds, 2016). Quality is a dynamic condition that affects products, services, processes, people, and the environment that meets or exceed expectations, so that service quality is defined as an effort to meet consumer needs and desires and the accuracy of their delivery in balancing consumer expectations (Altuntas \& Kansu, 2019; Lee et al., 2019). 
Service quality perceived by consumers will affect their satisfaction (Altaf et al., 2017). If the quality received is following customer expectations, then consumers will have a positive experience which will form their brand loyalty. There are five dimensions of service quality such as tangibility, reliability, responsiveness, assurance, and empathy (Magshoodi et al., 2019). Service quality that provides a satisfying experience for customers will make customers loyal and committed to the company (Espinosa et al., 2017; Monferrer et al., 2019). Consumer satisfaction with good service will become a positive experience (Kamath \& Prabhu, 2019). Consumer satisfaction positively affects word of mouth and the customer loyalty (Mukerjee, 2020). Therefore, we hypothesize:

$\mathrm{H} 2$ : Service quality has a positive effect on brand loyalty.

\section{Customer Value}

Customer value is not only gives satisfaction to customers but also provides happiness beyond customer expectations (Kotler \& Keller, 2016). Customer value has a close relationship with the consequences of receiving benefits or sacrifices, where the consequences are the impact felt by individuals or groups as a result of the consumption of goods or services as opposed to the provision of the goods (Foroudi et al., 2019; Streukens \& Leroi-Werelds, 2016). Customer value is the result of the customer benefits: economic, social, and relational to the customer sacrifices (price, time, effort, risk, and comfort) (Rubio et al., 2019).

Customer value dimension consists of functional, emotional, and social value (Anouze $\&$ Alamro, 2019). A functional value is the customer's perceived usefulness from the product or service attributes in terms of product or service installation, personnel, and service quality (Jamshidi et al., 2018). Meanwhile, emotional value is a feeling or affective state created through consumption experience, and social value is the acceptance of utilities at the individual level with the social environment (Maharani et al., 2020). The embedded value resulting from the customer's positive functional, emotional and social value will make the customer loyal. The emotional component is crucial and should be included along with other components (Razzaq et al., 2019). Hence, we hypothesize:

H3: Customer value has a positive effect on brand loyalty.

\section{Brand Loyalty}

Loyalty refers to the form of decision-making behavior to make a continuous purchase of goods or services from a selected company (Boateng et al., 2020; Loureiro, 2013). Brand loyalty is the extent to which customers show a positive attitude towards a brand comitment to a particular brand (Mowen \& Minor, 2010; Rambocas \& Arjoon, 2019). Loyal customers might repurchase because of the their positive feelings toward a brand (Boateng et al., 2020; Parihar \& Dawra, 2020). Customer loyalty will bring positive information to the closest people, friends, family, and even the customer community (Jalilvand, 2017). Therefore, this study proposes a hypothesis:

H4: Brand loyalty has a positive effect on brand equity.

\section{Brand Equity}

Brand equity is a set of assets and liabilities associated with a brand, name, and symbol that can make or reduce the value provided by a product or service (Altaf et al., 2017; Arora \& 
Neha, 2016; Jamshidi et al., 2018). Brand equity includes how the brand will provide value to the company by making an effective strategy in creating a memorable brand identity and has strong attributes that inherent in the community (Parihar \& Dawra, 2020; Saleh et al., 2017). Brand equity helps consumers in processing, interpreting, and storing information about a product or service that can affect consumer confidence in purchasing decisions. It also related to customer familiarity toward the brand and its attributes (Altaf et al., 2017; Kataria \& Saini, 2019; Kim \& Lee, 2020). Brand equity gives the impression of quality and brand association that can increase consumer satisfaction in using products or services from consumers loyalty (Asnawi et al., 2019; Espinosa et al., 2018; Saleh et al., 2017). Brand equity has two perspectives: the consumers' perspective and the company's perspective (Altaf et al., 2017).

\section{METHODS}

The approach used is quantitative research with confirmatory factors analysis by building a Structural Equation Modeling (SEM) (Hair et al., 2014). The population in this study is BCA customers in the Surabaya. This research was conducted on December 2019 to February 2020 with purposive sampling. There are 215 respondents who are selected based on the following criteria: (1) BCA customers who domiciled in Surabaya; (2) active customers who conduct financial transactions at BCA for at least one year; and (3) utilizing ATM services, mobile banking, and other service facilities. This study uses primary data. The questionnaire uses interval scale of 1-9 from "strongly disagree" to "strongly agree."

Exogenous variables in this study are brand image (X1), service quality (X2), and customer value (X3). In comparison, there are two endogenous variables: brand loyalty $(\mathrm{Z})$ as the intervening dependent variable and brand equity $(\mathrm{Y})$ as the dependent variable. Each exogenous variable also has a measurement indicator. Brand image (X1) has seven indicators: friendly (x11), gentle (x12), trust (x13), innovative (x14), accurate (x15), modern (x16), and easy to use (x17). Service quality (X2) has five indicators: tangible (x21), reliable (x22), responsive (x23), assurance (x24), and empathy (x25). Customer value (X3) has three indicators: functional (x31), emotional (x32), social (x33). Brand loyalty (Z) has three indicators: main choice (z11), words of mouth (z12), reference (z13). Brand equity (Y) has three indicators: brand awareness (y11), brand association (y12), and perceived quality (y13).

\section{RESULT AND DISCUSSION Validity and Reability Test}

Each question in the questionnaire is a research instrument that must be tested with a certain standard size so that the questionnaire results are valid and reliable to be used in research. From the total sample of 215 respondents, with a significant level of 5\%, the r-value of table 0.138 was obtained. The research instrument is said to be valid if $r$ count $>r$ table. From the results, all indicators have a calculated $r$-value greater than the $r$ table, except the question for indicator $\mathrm{x} 11$ of 0.020 . Hence, in the study, all indicators are valid except for statement $\mathrm{x} 11$. The validity test result is presented in Table 1. While the Cronbach's Alfa test results obtained a value of 0.851 which means greater than 0.700 , then the question items in the questionnaire used in this study are reliable. The reability test result is presented in Table 2. 
Dewi, R. \& Handriana, T.

Unlocking brand equity through brand image, service quality, and customer value

\section{Confirmatory Factor Analysis Exogenous Construct}

Based on data processing with Stata 14, Appendix 1 shows confirmatory factors analysis (CFA) on exogenous variables aims to test the unidimensionality of the indicators forming exogenous and endogenous latent variables (Akroush \& Mahadin, 2019). The latent variable or exogenous construct consists of 3 variables with 15 observed variables as their constituents. In the modeling of CFA, loading factors mean the correlation between the indicator and the latent construct. An indicator with a value of 0.5 has a weak correlation, such as latent constructs X1 including x11, x12, and x15. Meanwhile, the rest is used to build the full model. In comparison, all indicators on latent variables X2 and X3 are all used in building the model.

\section{Confirmatory Factors Analysis of Endogenous Constructions}

Appendix 2 shows the result of CFA analysis toward endogenous variables with six observed variables as their constituents. There are no indicators with values below 0.5 . Then, all indicators are used in building the model. The loading factor indicator's extraction results with the variables can be continued to build a complete model.

Table 1 . Validity Test

\begin{tabular}{lcccc}
\hline Latent Constructs & Observed Variables & r table & r count & Information \\
\hline Brand Image (X1) & Friendly (x11) & 0.138 & 0.020 & Invalid \\
& Gentle (x12) & 0.138 & 0.167 & Valid \\
& Trust (x13) & 0.138 & 0.383 & Valid \\
& Innovative (x14) & 0.138 & 0.339 & Valid \\
& Accurate (x15) & 0.138 & 0.337 & Valid \\
& Modern (x16) & 0.138 & 0.339 & Valid \\
& Easy to Use (x17) & 0.138 & 0.367 & Valid \\
Service Quality (X2) & Tangible (x21) & 0.138 & 0.487 & Valid \\
& Reliable (x22) & 0.138 & 0.623 & Valid \\
& Responsive (x23) & 0.138 & 0.670 & Valid \\
& Assurance (x24) & 0.138 & 0.625 & Valid \\
Customer Value (X3) & Empathy (x25) & 0.138 & 0.620 & Valid \\
& Functional (x31) & 0.138 & 0.663 & Valid \\
& Emotional (x32) & 0.138 & 0.605 & Valid \\
Brand Loyalty (Z) & Social (x33) & 0.138 & 0.650 & Valid \\
& Main Choice (z11) & 0.138 & 0.609 & Valid \\
& Words of Mouth (z12) & 0.138 & 0.610 & Valid \\
Brand Equity (Y) & Reference (z13) & 0.138 & 0.589 & Valid \\
& Brand Awareness (y11) & 0.138 & 0.552 & Valid \\
& Brand Associations (y11) & 0.138 & 0.641 & Valid \\
& Perceived Quality (y13) & 0.138 & 0.540 & Valid \\
\hline
\end{tabular}

Table 2. Reliability Test

\begin{tabular}{lccc}
\hline Latent Constructs & Cronbach's Alpha & Critical Value & Information \\
\hline Brand Image (X1) & 0.7435 & 0.700 & Reliable \\
Service Quality (X2) & 0.8251 & 0.700 & Reliable \\
Customer Value (X3) & 0.8253 & 0.700 & Reliable \\
Brand Loyalty (Z) & 0.7198 & 0.700 & Reliable \\
Brand Equity (Y) & 0.7358 & 0.700 & Reliable \\
\hline
\end{tabular}

\section{Structural Equation Modeling}

The model was built to test the models and hypotheses developed in this study. The model is tested in two ways: the significance test of causality through the regression coefficient test and the model suitability test. 


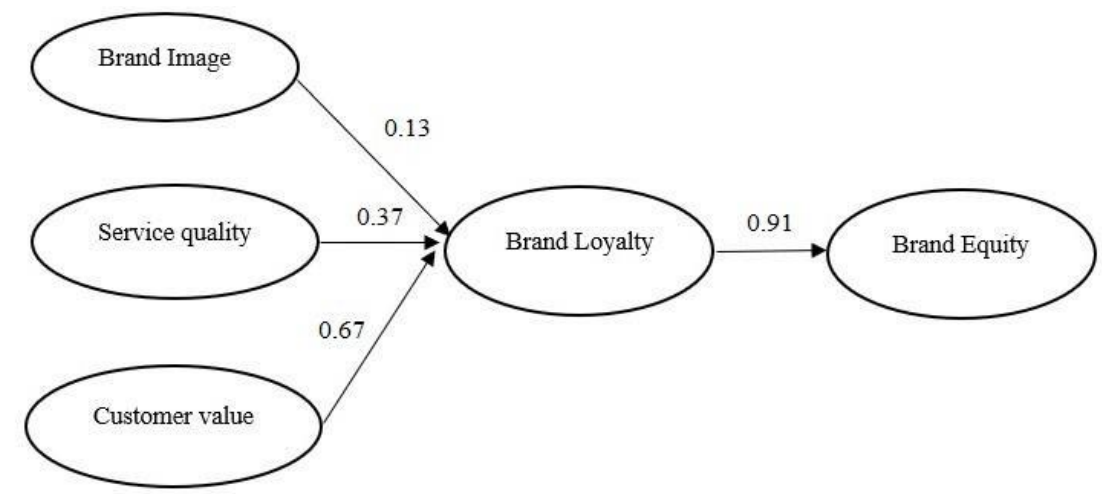

Figure 1. Result of Model Testing

Furthermore, Appendix 5 explains the regression results of the full model between the latent variables and each indicator that meets the study's requirements. Table 3 shows the summary of hypothesis testing that brand image positively affects brand loyalty (H1). It can be seen from the path of 0.13 that service quality positively affects brand loyalty $(\mathrm{H} 2)$, and customer value has a positive effect on brand loyalty (H3). From the results, all z values are above 1.96 can be interpreted as all variables and indicators in the model are fit.

Table 3. Hypothesis Testing

\begin{tabular}{lllcc}
\hline Hypothesis & \multicolumn{2}{c}{ Description } & Path Coeff & Information \\
\hline H1 & Brand Image (X1) & Brand Loyalty (Z) & 0.13 & Supported \\
H2 & Service Quality (X2) & Brand Loyalty (Z) & 0.37 & Supported \\
H3 & Customer Value (X3) & Brand Loyalty (Z) & 0.67 & Supported \\
H4 & Brand Loyalty (Z) & Brand Equity (Y) & 0.91 & Supported \\
\hline
\end{tabular}

Brand loyalty has a positive effect on brand equity (H4). It can be seen from the path of 0.91 and, it is known that $\mathrm{z}$ value $17.11>1.96$ can be interpreted as the variable and indicators in the model is fit. In Structural Equation Modeling (SEM), a goodness of fit test is needed for the model built, shown in Appendix 4 with RMSE $0.061 \leq 0.08$, TLI $0.914 \geq 0.90$, and CFI $0.28 \geq 0.90$ reflect fit structural modeling.

\section{Discussion}

PT. Bank Central Asia, Tbk strives to provide excellent service to customers with various innovations and creativity in line with digital technology advancement. Antecedents for building brand loyalty are influenced by brand image, service quality, and customer value in this research. Brand loyalty has a strategic role in forming brand equity. Companies must work hard to get loyal customers to establish long-term relationships and commitment between customers and the company to form brand equity. With many savings customers, bank should provide a secure saving and transactions.

Brand image in this study is proven to have a strong influence on the consumer minds which ultimately affects their brand loyalty (Altaf et al., 2017; Bapat, 2017). Consumers who have good experience receive expected quality of service which will form a customer commitment (Espinosa et al., 2018; Hapsari, 2017; Hoang, 2019; Parihar \& Dawra, 2020). Likewise, customer value has a strong influence on brand loyalty if it functionally, emotionally, and socially meet customer expectations (Kim \& Lee, 2020). 
Unlocking brand equity through brand image, service quality, and customer value

Having loyal customers will be very beneficial for the company because customers will not be easy to move to other banks (Altaf et al., 2017). It is essential to build a positive brand image in customers mind because of fierce competition in banking industry (Boateng et al., 2019; Parihar \& Dawra, 2020; Rubio et al., 2019). The existence of digital technology services that are always updated and meet the customers need (Asnawi et al., 2019; Kim \& Lee, 2020; Pan \& Ha, 2019; Saleh et al., 2017). ATM services in various outlets, enable customers to withdraw, save, transfer money, pay water bills, electricity, and many other conveniences. If the customer cannot go to the ATM to make e-money payments, they can use mobile banking service that always updates its features. With mobile banking, consumer can make an easy, fast, and safe transactions.

Customers feel safe using saving services due to their perception that the bank is financially healthy. Besides, BCA's awards prove that BCA continues to be a trusted bank, a very healthy bank, and has a quality service that is always up to date. Based on its strong goal to provide an excellent service to its customers, a bank usually build technology infrastructure and customer-focus employees (Akroush \& Mahadin, 2019; Hoang, 2019; Pan \& Ha, 2019). Customers feel the value received both functionally, emotionally, and socially has met their expectations, so this needs attention from the company (Razzaq et al., 2019). Therefore, maintaining consumer loyalty is an effective strategy to attract new customers (Mohsin \& Aftab, 2013; Pan \& Ha, 2019). Brand loyalty will make customers show the ability to recognize or recall a brand from a company product or service, the brand will give a positive impression in the customer's perception, and the customers have the experience of receiving pleasant service quality with the brand so that it will strengthen brand equity (Altaf et al., 2017; Saleh et al., 2017).

\section{CONCLUSION}

This study concludes that brand equity that mediated by brand loyalty are influenced by brand image, service quality, and customer value in this research. This research contributes to marketing management in service company. Brand equity will provide value to the company to make the right strategy to make a memorable brand and its strong attributes attached to the community. In marketing management, it is essential to be a market leader and have a high market share in the fierce competition by influencing consumer perception. The company has tried to build a positive brand image captured in customers' minds to become the customer's first choice.

The implication of this research is providing managerial insights and enriching knowledge related to how brand image, service quality, and customer value toward brand loyalty in a banking company. Therefore, the company needs loyal customers who has a significant role to build its brand equity. Companies must maintain a brand image as a healthy and safe bank by continuously providing quality services. Companies must also be responsive to adapt its service based on consumer needs by providing up to date, fresh, and value-added services to customers. Hence, customers will have a positive and satisfying experience that will encourage them to be loyal to the brand and strengthen brand equity.

However, this study has limitations such as uses three endogenous variables (brand image, service quality, and customer value) to identify its impact on brand loyalty and brand 
equity. Therefore, future studies can use more endogenous variables such as customer engagement and experience to determine factors that influence brand loyalty and brand equity.

\section{REFERENCES}

Akroush, M. \& Mahadin, B. (2019). An Intervariable Approach to Customer Satisfaction and Loyalty in the Internet Service Market. Internet Research, 29(4), 772798. https://doi.org/10.1108/IntR-12-2017-0514.

Alić, A., Činjarević, M., \& Agić, E. (2020). The Role of Brand Image in Consumer-Brand Relationships: Similarities and Differences between National and Private Label Brands. Management and Marketing, 15(1), 1-16. https://doi.org/10.2478/mmcks-2020-0001.

Altaf, M., Iqbal, N., Mokhtar, S. S. M., \& Sial, M. H. (2017). Managing Consumer-Based Brand Equity through Brand Experience in Islamic Banking. Journal of Islamic Marketing, 8(2), 218-242. https://doi.org/10.1108/JIMA-07-2015-0048.

Altuntas, S. \& Kansu, S. (2019). An Innovative and Integrated Approach Based on Servqual, Qfd and Fmea for Service Quality Improvement: A Case Study. Kybernetes, 49(10), 2419-2453. https://doi.org/10.1108/K-04-2019-0269.

Anouze, A. L. M. \& Alamro, A. S. (2019). Factors Affecting Intention to use E-Banking in Jordan. International Journal of Bank Marketing, 38(1), 86-112. https://doi.org/10.1108/IJBM-10-2018-0271.

Arora, S. \& Neha. (2016). Determinants of Customer-Based Brand Equity: A Study of Public and Private Banks. Global Business Review, 17(4), 905-920. https://doi.org/10.1177/0972150916645693.

Asnawi, N. \& Sukoco, B. M.. (2019). The Role of Service Quality Within Indonesian Customers Satisfaction and Loyalty and Its Impact on Islamic Banks. Journal of Islamic Marketing, 11(1), 192-212. https://doi.org/10.1108/JIMA-03-2017-0033.

Bapat, D. (2017). Exploring the Antecedents of Loyalty in the Context of Multi-Channel Banking. International Journal of Bank Marketing, 35(2), 174186. https://doi.org/10.1108/IJBM-10-2015-0155.

BCA. (2020). Tanggung Jawab Sosial Perusahaan. Retrieved April 282020 from https://www.bca.co.id/tentang-bca/korporasi/csr.

Boateng, H., Kosiba, J. P., Adam, D. R., Ofori, K. S., \& Okoe, A. F. (2020). Examining Brand Loyalty from an Attachment Theory Perspective. Marketing Intelligence \& Planning, 38(4), 479-494. https://doi.org/10.1108/MIP-03-2019-0161.

Chakraborty, D. (2019). Factors Responsible for Making Young Urban Consumers Brand Loyal: A Study on Mobile Network Operators. Journal of Management Development, 38(7), 616-636. https://doi.org/10.1108/JMD-01-2019-0029.

Chang, W. J. (2020). Experiential Marketing, Brand Image and Brand Loyalty: A Case Study of Starbucks. British Food Journal, 123(1), 209-223. https://doi.org/10.1108/BFJ-012020-0014. 
Dewi, R. \& Handriana, T.

Unlocking brand equity through brand image, service quality, and customer value

Espinosa, J. A., Ortinau, D. J., Krey, N., \& Monahan, L. (2018). I'll Have the Usual: How Restaurant Brand Image, Loyalty, and Satisfaction Keep Customers Coming Back. Journal of Product \& Brand Management, 27(6), 599-614. https://doi.org/10.1108/JPBM-10-2017-1610.

Flores-Hernández, J. A., Cambra-Fierro, J. J., \& Vázquez-Carrasco, R. (2020). Sustainability, Brand Image, Reputation, and Financial Value: Manager Perceptions in an Emerging Economy Context. Sustainable Development, 28(4), 935-945. https://doi.org/10.1002/sd.2047.

Foroudi, P., Cuomo, M. T., \& Foroudi, M. M. (2019). Continuance Interaction Intention in Retailing: Relations Between Customer Values, Satisfaction, Loyalty, and Identification. Information Technology \& People, 33(4), 1303-1326. https://doi.org/10.1108/ITP-09-2018-0421.

Guci, D. A., Ghazali, P. L., Nst, A. M., Fajrillah, Abas, S., \& Fadhli, M. (2020). Analyze the Relationship of Brand Image and Advertisement Towards Decision to Become A Customer on Bank BNI Batam Branch. Journal of Physics: Conference Series, 1477(2), 1-3. https://doi.org/10.1088/1742-6596/1477/2/022008.

Hair, J., Hult, G., Ringle, C., \& Sarstedt, M. (2014). A Primier On Partial Least Squares Structural Equation Modeling (PLS-SEM). America: SAGE Publication, Inc.

Hamouda, M. (2019). Omni-Channel Banking Integration Quality and Perceived Value as Drivers of Consumers' Satisfaction and Loyalty. Journal of Enterprise Information Management, 32(4), 608-625. https://doi.org/10.1108/JEIM-12-2018-0279.

Hapsari, R., Clemes, M. D., \& Dean, D. (2017). The Impact of Service Quality, Customer Engagement, and Selected Marketing Constructs on Airline Passenger Loyalty. International Journal of Quality and Service Sciences, 9(1), 21-40. https://doi.org/10.1108/IJQSS-07-2016-0048.

Hoang, D. P. (2019). The Central Role of Customer Dialogue and Trust in Gaining Bank Loyalty: An Extended SWICS Model. International Journal of Bank Marketing, 37(3), 711-729. https://doi.org/10.1108/IJBM-03-2018-0069.

Maghsoodi, A. I., Saghaei, A., \& Hafezalkotob, A. (2019). Service Quality Measurement Model Integrating an Extended SERVQUAL Model and A Hybrid Decision Support System. European Research on Management and Business Economics, 25(3), 151-164. https://doi.org/10.1016/j.iedeen.2019.04.004.

Jalilvand, M. R., Salimipour, S., Elyasi, M., \& Mohammadi, M. (2017). Factors Influencing Word of Mouth Behaviour in the Restaurant Industry. Marketing Intelligence \& Planning, 35(1), 81-110. https://doi.org/10.1108/MIP-02-2016-0024.

Jamshidi, D., Keshavarz, Y., Kazemi, F., \& Mohammadian, M. (2018). Mobile Banking Behavior and Flow Experience: an Integration of Utilitarian Features, Hedonic Features and Trust. International Journal of Social Economics, 45(1), 57-81. https://doi.org/10.1108/IJSE-10-2016-0283. 
Kafe BCA. (2020). Torehkan Prestasi, BCA Pertahankan Posisi Pertama untuk Indonesia's Most Valuable Brand. Retrieved 8 July 2020 from https://www.bca.co.id/id/TentangBCA/Korporasi/Kafe-BCA.

Kamath, P. R., Pai, Y. P., \& Prabhu, N. K. P. (2019). Building Customer Loyalty in Retail Banking: A Serial-Mediation Approach. International Journal of Bank Marketing, 38(2), 456-484. https://doi.org/10.1108/IJBM-01-2019-0034.

Kartika, T., Firdaus, A., \& Najib, M. (2019). Contrasting the Drivers of Customer Loyalty Financing and Depositor Customer, Single, and Dual Customer, In Indonesian Islamic Bank. Journal of Islamic Marketing. 11(4), 933-959. https://doi.org/10.1108/JIMA-042017-0040.

Kataria, S. \& Saini, V. (2019). The Mediating Impact of Customer Satisfaction in Relation of Brand Equity and Brand Loyalty: An Empirical Synthesis and Re-Examination. South Asian Journal of Business Studies, 9(1), 62-87. https://doi.org/10.1108/SAJBS-03-20190046.

Kim, S. \& Lee, S. A. (2020). The Role of Marketing Communication Mix on Korean Customers' Coffee Shop Brand Evaluations. Journal of Hospitality and Tourism Insights, 3(3), 291-309. https://doi.org/10.1108/JHTI-07-2019-0097.

Kotler, P. \& Keller, K. L. (2016). Marketing Management (15th ed.). United States: Pearson Education,Inc.

Lee, C. H., Zhao, X., \& Lee, Y. C. (2019). Service Quality Driven Approach for Innovative Retail Service System Design and Evaluation: A Case Study. Computers and Industrial Engineering, 135(June), 275-285. https://doi.org/10.1016/j.cie.2019.06.001.

Lin, J., Lobo, A., \& Leckie, C. (2017). Green Brand Benefits and Their Influence on Brand Loyalty. Marketing Intelligence \& Planning, 35(3), 425-440. https://doi.org/10.1108/MIP-09-2016-0174.

Liu, M.T., Liu, Y., Mo, Z., Zhao, Z., \& Zhu, Z. (2018). How CSR Influences Customer Behavioral Loyalty in the Chinese Hotel Industry. Asia Pacific Journal of Marketing and Logistics, 32(1), 1-22. https://doi.org/10.1108/APJML-04-2018-0160.

Loureiro, S. M. C. (2013). The Effect of Perceived Benefits, Trust, Quality, Brand Awareness/Associations, and Brand Loyalty on Internet Banking Brand Equity. International Journal of Electronic Commerce Studies, 4(2), 139-158. https://doi.org/10.7903/ijecs.1000.

Maharani, N., Helmi, A., Mulyana, A., \& Hasan, M. (2020). In-Store Promotion and Customer Value on Private Label Product Purchase Intention. Innovative Marketing, 16(4), 104116. https://doi.org/10.21511/im.16(4).2020.09.

Malhotra, N. K. (2014). Basic Marketing Research: Pearson New Internatinal Edition (4th ed.). England: Pearson Education.

Mohsin, B. M. \& Aftab, M. (2013). Incorporating Attitude Towards Halal Banking in An Integrated Service Quality, Satisfaction, Trust, and Loyalty Model in Online Islamic 
Dewi, R. \& Handriana, T.

Unlocking brand equity through brand image, service quality, and customer value

Banking Context. International Journal of Bank Marketing, 3(1), 6-23. https://doi.org/10.1108/02652321311292029.

Monferrer, D., Moliner, M. A., \& Estrada, M. (2019). Increasing Customer Loyalty through Customer Engagement in the Retail Banking Industry. Spanish Journal of Marketing ESIC, 23(3), 461-484. https://doi.org/10.1108/SJME-07-2019-0042.

Mowen, J.C. \& Minor, M. (2010). Consumer Behavior (5th ed.). United States: Prentice Hall,Inc.

Mukerjee, K. (2020). Impact of Self-Service Technologies in Retail Banking on Cross-Buying and Word of Mouth. International Journal of Retail \& Distribution Management, 48(5), 485-500. https://doi.org/10.1108/IJRDM-08-2019-0261.

Otoritas Jasa Keuangan. (2004). Indonesian Banking Booklet. Jakarta: Otoritas Jasa Keuangan.

Pan, H. \& Ha, H. (2019). When Do Interest Rates Matter? Two Methodological Approaches to Loyalty. Asia Pacific Journal of Marketing and Logistics, 32(1), 4664. https://doi.org/10.1108/APJML-06-2018-0229.

Parihar, P. \& Dawra, J. (2020). The Role of Customer Engagement in Travel Services. Journal of Product \& Brand Management, 29(7), 899-911. https://doi.org/10.1108/JPBM-112018-2097.

Pérez, S., Garrido, A., \& Martos, M. (2019). Identifying a Private-Label Supplier on National Brand. Journal of Product \& Brand Management, 28(3), 432-443. https://doi.org/10.1108/JPBM-06-2018-1908.

Putra, D. (2019)._Ini Dia Bank-Bank Peraih Infobank Awards 2019. Retrivied on April 172020 from https://infobanknews.com/topnews/ini-dia-bank-bank-peraih-infobank-awards$2019 /$.

Rambocas, M. \& Arjoon, S. (2019). Brand Equity in Caribbean Financial Services: The Moderating Role of Service Providers. International Journal of Bank Marketing, 38(3), 642-670. https://doi.org/10.1108/IJBM-05-2019-0167.

Razzaq, Z., Razzaq, A., Yousaf, S., Akram, U., \& Hong, Z. (2019). The Impact of Customer Equity Drivers on Loyalty Intentions among Chinese Banking Customers: The Moderating Role of Emotions. Asia Pacific Journal of Marketing and Logistics, 31(4), 980-1002. https://doi.org/10.1108/APJML-10-2017-0243.

Rubio, N., Villaseñor, N., \& Yagüe, M. J. (2019). Customer's Loyalty and Trial Intentions Within the Retailer: The Moderating Role of Variety-Seeking Tendency. Journal of Consumer Marketing, 36(5), 620-632. https://doi.org/10.1108/JCM-10-2017-2391.

Saleh, M. A., Quazi, A., Keating, B., \& Gaur, S. S. (2017). Quality and Image of Banking Services: A Comparative Study of Conventional and Islamic Banks. International Journal of Bank Marketing, 35(6), 878-902. https://doi.org/10.1108/IJBM-08-20160111. 
Streukens, S. \& Leroi-Werelds, S. (2016). PLS FAC-SEM: An Illustrated Step-by-Step Guideline to Obtain A Unique Insight in Factorial Data. Industrial Management \& Data Systems, 116(9), 1922-1945. https://doi.org/10.1108/IMDS-07-2015-0318.

Appendix 1. Confirmatory Factor Analysis Exogenous Variable

\begin{tabular}{ccccc}
\hline Latent Constructs & Observed Variables & Loading Factor & Z & p>IzI \\
\hline Brand Image (X1) & Friendly (x11) & 0.28 & 3.89 & 0.00 \\
& Gentle (x12) & 0.42 & 6.44 & 0.00 \\
& Trust (x13) & 0.69 & 14.62 & 0.00 \\
& Innovative (x14) & 0.73 & 16.07 & 0.00 \\
& Accurate (x15) & 0.48 & 7.77 & 0.00 \\
& Modern (x16) & 0.63 & 12.05 & 0.00 \\
& Easy to use (x17) & 0.55 & 9.50 & 0.00 \\
Service Quality (X2) & Tangibles (x21) & 0.51 & 9.40 & 0.00 \\
& Reliability (x22) & 0.78 & 22.30 & 0.00 \\
& Responsiveness (x23) & 0.82 & 25.21 & 0.00 \\
& Assurance (x24) & 0.74 & 18.92 & 0.00 \\
& Empathy (x25) & 0.64 & 13.43 & 0.00 \\
Customer Value (X3) & Functional (x31) & 0.86 & 27.71 & 0.00 \\
& Emotional (x32) & 0.83 & 25.33 & 0.00 \\
& Social (x33) & 0.67 & 15.30 & 0.00 \\
\hline
\end{tabular}

Appendix 2. Confirmatory Factor Analysis Endogen Variable

\begin{tabular}{lcccc}
\hline Latent Constructs & Observed Variables & Loading Factor & Z & p>IzI \\
\hline Brand Loyalty (Z) & Main Choice (z11) & 0.68 & 13.37 & 0.00 \\
& Words of Mouth (z12) & 0.64 & 11.96 & 0.00 \\
& Reference (z13) & 0.71 & 14.24 & 0.00 \\
Brand Equity (Y) & Brand Awareness (y11) & 0.62 & 9.91 & 0.00 \\
& Brand Associations (y12) & 0.59 & 9.32 & 0.00 \\
& Perceived Quality (y13) & 0.52 & 7.90 & 0.00 \\
\hline
\end{tabular}

Appendix 3. Regression Result

\begin{tabular}{lcccccc}
\hline \multicolumn{2}{c}{ Description } & Loading Factor & $\mathbf{Z}$ & p>IzI & Information \\
\hline Brand Image & $\rightarrow$ & Brand Loyalty & 0.13 & 2.36 & 0.02 & Significant \\
Service Quality & $\rightarrow$ & Brand Loyalty & 0.37 & 5.31 & 0.00 & Significant \\
Customer Value & $\rightarrow$ & Brand Loyalty & 0.67 & 10.18 & 0.00 & Significant \\
Brand Loyalty & $\rightarrow$ & Brand Equity & 0.91 & 17.11 & 0.00 & Significant \\
\hline
\end{tabular}

Appendix 4. Goodness of Fit

\begin{tabular}{lccc}
\hline Criteria & Cut of Value & Result & Evaluation \\
\hline RMSE & $\leq 0.08$ & 0.061 & Good \\
TLI & $\geq 0.90$ & 0.914 & Good \\
CFI & $\geq 0.90$ & 0.928 & Good \\
\hline
\end{tabular}


Dewi, R. \& Handriana, T.

Unlocking brand equity through brand image, service quality, and customer value

Appendix 5. Regression Weight Structural Equation Model

\begin{tabular}{lclccc}
\hline & Description & Loading Factor & $\mathbf{Z}$ & p>IzI \\
\hline Brand Image (X1) & $\rightarrow$ & Trust (x13) & 0.74 & 14.62 & 0.00 \\
Brand Image (X1) & $\rightarrow$ & Innovative (x14) & 0.72 & 16.07 & 0.00 \\
Brand Image (X1) & $\rightarrow$ & Modern (x16) & 0.60 & 12.05 & 0.00 \\
Brand Image (X1) & $\rightarrow$ & Easy to Use (x17) & 0.55 & 9.50 & 0.00 \\
Service Quality (X2) & $\rightarrow$ & Tangibles (x21) & 0.51 & 9.40 & 0.00 \\
Service Quality (X2) & $\rightarrow$ & Reliability (x22) & 0.78 & 22.30 & 0.00 \\
Service Quality (X2) & $\rightarrow$ & Responsiveness (x23) & 0.81 & 25.21 & 0.00 \\
Service Quality (X2) & $\rightarrow$ & Assurance (x24) & 0.74 & 18.92 & 0.00 \\
Service Quality (X2) & $\rightarrow$ & Empathy (x25) & 0.64 & 13.43 & 0.00 \\
Customer Value (X3) & $\rightarrow$ & Functional (x31) & 0.85 & 27.71 & 0.00 \\
Customer Value (X3) & $\rightarrow$ & Emotional (x32) & 0.80 & 25.33 & 0.00 \\
Customer Value (X3) & $\rightarrow$ & Social (x33) & 0.72 & 15.30 & 0.00 \\
Brand Loyalty (Z) & $\rightarrow$ & Main Choice (z11) & 0.68 & 13.37 & 0.00 \\
Brand Loyalty (Z) & $\rightarrow$ & Words of Mouth (z12) & 0.64 & 11.96 & 0.00 \\
Brand Loyalty (Z) & $\rightarrow$ & Reference (z13) & 0.71 & 14.24 & 0.00 \\
Brand Equity (Y) & $\rightarrow$ & Brand Awareness (y11) & 0.62 & 9.91 & 0.00 \\
Brand Equity (Y) & $\rightarrow$ & Brand Associations (y12) & 0.59 & 9.32 & 0.00 \\
Brand Equity (Y) & $\rightarrow$ & Perceived Value (y13) & 0.52 & 7.90 & 0.00 \\
Brand Image (X1) & $\rightarrow$ & Brand Loyalty (Z) & 0.13 & 2.36 & 0.02 \\
Service Quality (X2) & $\rightarrow$ & Brand Loyalty (Z) & 0.37 & 5.31 & 0.00 \\
Customer Value (X3) & $\rightarrow$ & Brand Loyalty (Z) & 0.67 & 10.18 & 0.00 \\
Brand Loyalty (Z) & $\rightarrow$ & Brand Equity (Y) & 0.91 & 17.11 & 0.00 \\
\hline & & & & & \\
\hline
\end{tabular}

